\title{
Confidentiality of academy panel challenged by environmentalists
}

[WASHINGTON] Three US environmental groups have filed suit to block construction of a \$1.1-billion nuclear weapons research facility at Lawrence Livermore National Laboratory in California. They are arguing that a panel of scientists formed to advise the Department of Energy on the project should have carried out its work in public.

The planned National Ignition Facility (NIF) is intended to simulate conditions in nuclear explosions, and its construction has already been given the go-ahead.

But the suit has wider implications, as it highlights growing concerns about the extent to which members of panels set up by the National Academy of Science (NAS) may be under a legal obligation to disclose any advice they provide.

In a lawsuit filed in the Federal District Court for the District of Columbia, the three groups - the Natural Resources Defense Council, Western States Legal Foundation and Tri-Valley Citizens Against a Radioactive Environment - are seeking an injunction prohibiting the department from using any of the technical advice it receives from the Inertial Confinement Fusion (ICF) Committee.

This committee was set up under the auspices of the NAS to prepare a report for the energy department on the scientific and technical readiness of the facility. Its findings

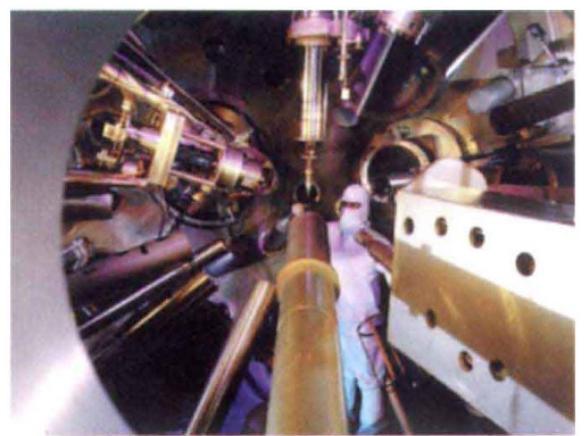

Off beam? Courts may decide whether advice on laser research (above) should be made public.

are expected to be made public next month.

The environmental groups claim that the ICF committee should be subject to the Federal Advisory Committee Act, which requires such panels to operate in public. The suit also claims that the panel's membership violates the act because it is unfairly balanced and includes members with inappropriate special interests.

A spokeswoman for the energy department says that it had not reviewed the complaint, and declines to comment. But William Colglazier, executive officer of NAS and its subsidiary, the National Research Council, says the academy maintains that the act does not apply to its committees -

\section{US decision 'will not limit gene patents'}

[LONDON] The US Patent and Trademark Office has confirmed an informal announcement by one of its officials last week that it has decided to grant patents for expressed sequence tags (ESTs), the short sequences of DNA that uniquely identify whole genes expressed in cells (see Nature 385,$670 ; 1996$ ).

But the patent office says that, although any such patent would be based on the novelty and utility of ESTs as probes for the corresponding full-length gene - for example in forensic tests - it would not cover any further functions or uses of the gene. Many researchers in the field do not want the patents to cover such further functions.

Lawrence Goffney, deputy commissioner of patents and trademarks, says the decision means that any functions subsequently discovered for the gene whose EST is patented would be separately patentable, as long as they were not already obvious from the EST.

ESTs can be mass-produced from samples of messenger RNA, providing a quick way to $\log$ the thousands of genes being expressed in a cell at a particular time. Because it is principally commercial companies that have the high-throughput DNA-sequencing capabilities to find large numbers of ESTs, scientists have expressed concern at the idea that patents could be granted for ESTs in case these precluded further research on the corresponding genes.

As a result of the new decision, patent owners would be able to license other researchers to use the ESTs, but this would only cover research on the whole gene in rare cases where the EST encompasses the entire gene sequence.

John Doll, director of the biotechnology patent examining group at the patent office, says that the decision to grant patents for ESTs with demonstrated utilities as probes was made at the end of last year. No such patents have been granted, although the procedure has been initiated in a handful of cases. "We have approximately 350 [patent] applications that are claiming over 500,000 ESTs," says Doll.

Claire O'Brien despite a January ruling by a federal appeals court in a similar but unrelated case.

The case before the appeals court involved a panel formed by the NRC for the National Institutes of Health to revise guidelines on the care and use of laboratory animals. Animal rights organizations sued on the grounds that the panel should have followed the act's provisions.

If upheld, the appeals court ruling could force the academy to begin complying with the act in those instances, such as the NIF panel, where non-government committees are used by government agencies. The academy is appealing against the ruling. Until the appeal is completed, Colglaizer says, the energy department and NAS have agreed to continue the operations of the ICF panel unchanged.

The issue of the committee's membership has been simmering for some time. Thomas Cochran, director of the Natural Resources Defense Council's nuclear programme, complained to Bruce Alberts, chairman of $\mathrm{NRC}$, in a letter last December that "without question the current membership of the NRC's ICF committee is not balanced" and "is in clear violation of the NRC's policy" designed to ensure that committee reports are free from conflicts of interest or bias.

Ten members of the committee either have ties to the energy department's fusion programme or to Lawrence Livermore "or have already voiced very positive views regarding NIF," says Cochran. Several, including Steven Koonin, provost of California Institute of Technology and chairman of the panel, have served on earlier reviews of the ICF programme.

In response, Colglaizer says that the panel's composition reflects its narrow charge of determining whether there may be outstanding scientific and technical issues that should be resolved before starting to build NIF. The energy department had already reviewed and resolved the larger issue of whether NIF should be built, he says.

Colglazier says the NRC followed its normal procedures in picking members of the committee, with about half the members having "intimate knowledge" of ICF or the NIF project, and the rest chosen from other scientific disciplines who might bring a "fresh perspective".

Howard Crystal, an attorney representing the three environmental groups, said last week that District Judge Paul Friedman, who has been assigned to consider the suit, has not yet indicated when the case is likely to be dealt with.

DavidKramer 